\title{
OD PET LAHVÍ K DOBROTÁM
}

\section{Petr Holý a Eva Benešováa}

${ }^{a}$ Ústav biochemie a mikrobiologie, Vysoká škola chemickotechnologická v Praze, Technická 5, 16628 Praha 6 pholy382@seznam.cz,Eva.Benesova@vscht.cz

Klíčová slova: vanilin, kyselina tereftalová, potravinářský průmysl, plasty, recyklace

- https://doi.org/10.54779/chl20220061

Často poslouchám ráno rozhlasovou dvojku (ČRo2), kam do hudebního bloku moderátor Jakub Kaloč pravidelně vkládá krátké informace $\mathrm{z}$ vědy a techniky a někdy jako profesor Doudleba přináší př́spěvky i humorného rázu. Jednou v létě (1. 7. 2021) uvedl, že vanilkovou příchut' bude možno vyrábět $z$ plastových lahví ${ }^{1}$, běžně nazývaných jako PET lahve (PET - polyethylentereftalát). I když se to zprvu nezdálo, šlo o informaci zcela seriózní.

Při svém vstupu citoval z článků, které se objevily i v českých sdělovacích prostředcích ${ }^{2,3}$. Ty stručně popisovaly práci britských vědců, podle nichž lze pomocí geneticky upravené bakterie Escherichia coli přeměnit kyselinu tereftalovou na vanilin. V článcích je zdůrazněn velký význam této navržené technologie, která umožňuje zpracovat obtížný odpad na cenný produkt, který nachází široké uplatnění nejen v potravinářství, ale i v produktech kosmetického a farmaceutického průmyslu. Časopis „100+1“( cit. $^{2}$ ) na jedné straně označuje zmíněný postup jako „majstrštyk“ recyklace, na druhé straně práci britských vědců považuje za využití št'astné souhry okolností, nebot' kyselina tereftalová a vanilin mají - dle redaktorů - velmi podobnou chemickou strukturu, a proto se geneticky upravené bakterie vlastně prý ani moc nenadřou. Z pohledu chemika je jasné, že jde o laické hodnocení, obě struktury, tedy kyseliny tereftalové a vanilinu (4-hydroxy-3-methoxybenzaldehydu), sice obsahují benzenové jádro, jinak se ale dosti liší (obr. 1), takže chemik musí obdivovat, že si ty „breberky“ s požadovanými strukturními změnami poradí.

Pro bližší seznámení s postupem vedoucím $\mathrm{k}$ vanilinu musíme nahlédnout do článku, který britští vědci publikovali v časopise Green Chemistry ${ }^{4}$. Joana Sadlerová a Stephen Wallace z University of Edinburgh se rozhodli použít jako výchozí mikroorganismus vhodně upravenou bakterii $E$. coli, konkrétně se jednalo o kmen $E$. coli MG1655 RARE (RARE - reduced aromatic aldehyde reduction), jehož genom je cíleně modifikován tak, aby docházelo $\mathrm{k}$ redukci aromatických karboxylových kyselin pouze do stupně aldehydu ${ }^{5}$, což je pro cílový záměr důležitá vlastnost. Britští vědci ovšem předpokládali, že celá přeměna kyseliny tereftalové na vanilin se musí odehrát sledem navazujících enzymových reakcí (obr. 1), a proto museli genom tohoto mikroorganismu rozš́ríit o geny pocházející z dalších vhodně vybraných organismů. Konkrétně se jednalo o geny pro tereftalát-1,2-dioxygenasu (heterotrimer) a dehydrogenasu dihydroxy-3,5-cyklohexadien-1,4-dikarboxylové kyseliny z bakterie Comamonas sp., gen pro aldehydoxidoreduktasu CAR (carboxylic acid reductase) z bakterie Nocardia iowensis a gen pro mutantní formu katechol-O-methyltransferasy potkana obecného neboli Rattus norvegicus. Posledním vnášeným byl gen pro fosfopanteteinyltransferasu $\mathrm{z}$ bakterie Bacillus subtilis, která je nezbytná pro posttranslační modifikace aldehydoxidoreduktasy z Nocardia iowensis. Teprve pak buňky takto upraveného mikroorganismu, označeného nově jako $E$. coli RARE_pVanX, začaly díky pětikrokové enzymové přeměně produkovat vanilin, ovšem $\mathrm{v}$ počátku pouze s minimální konverzí kyseliny tereftalové. Úpravou podmínek, hlavně použitím vhodného média (M9 s glukosou a L-methioninem) o $\mathrm{pH} 5,5$, nastavením vhodné kultivační teploty na $22{ }^{\circ} \mathrm{C}$ a dále prídavkem butanolu pro zlepšení permeability buněk pro kyselinu tereftalovou ( $E$. coli neobsahuje transportér pro tuto látku do cytosolu) a oleylalkoholu pro separaci fází se autorům podařilo zlepšit počáteční produkci vanilinu $157 \mathrm{krá}$. Složitost procesu nechává však ještě mnoho možností $\mathrm{k}$ jeho dalšímu vylepšování, které by mohlo vést až $\mathrm{k}$ jeho průmyslovému využití; zatím použitý enzym zpracovává $1 \mathrm{mM}$ roztok kyseliny tereftalové se $79 \%$ konverzí na vanilin za 24 hodin.

Syntetický vanilin se vyrábí ve značném množství a jeho spotřeba stále vzrůstá, od 37 tisíc tun v roce 2018 k očekávaným 57 tisícům tun v roce 2025 (cit. $\left.{ }^{4}\right)$. Většina z tohoto množství se vyrábí z guajakolu a kyseliny glyoxalové, jiný postup vychází $\mathrm{z}$ eugenolu ${ }^{6}$ a přibližně $15 \%$ produkce připadá na chemické nebo mikrobiální zpracování ligninu? ${ }^{7}$. Tyto zavedené postupy netrpí nedostatkem výchozích surovin a jsou schopny pokrýt stoupající potřebu. Jiná je situace u př́rodního vanilinu, který je obsažen v nezralých fermentovaných tobolkách (obvykle nazývaných lusky) několika druhů orchidejí z rodu Vanilla v množství 1-3 \%. Vanilkovníky (někdy též nazývané jako

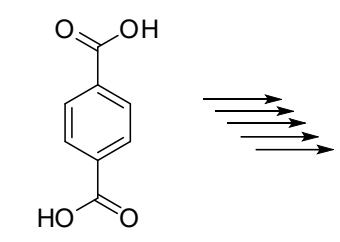

kyselina tereftalová

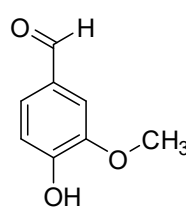

vanilin
Obr. 1. Přeměna kyseliny tereftalové na vanilin pomocí pěti navazujících enzymových kroků 
vanilovníky nebo také zkráceně jako vanilka) se pěstují v tropických oblastech; největším světovým producentem vanilky se stala roku 2020 Indonésie, na druhém místě je Madagaskar, na třetím Čína. Celkem se vanilkovníky pěstují až ve 13 zemích, ovšem další státy mají produkci již značně nižšśi. Celková roční sklizeň lusků nyní kolísá kolem 6 tisíců tun ${ }^{8}$. Celý proces pěstování rostlin i následné zpracování lusků jsou postupy velmi náročné na lidskou práci (např́klad je nutné umělé opylování) a sklizeň je často ovlivňována prírodními vlivy, proto je přírodní vanilky v současné době nedostatek a její cena roste. Syntetický vanilin je výrazně levnější než vanilkový extrakt (v roce 2012 zhruba $100 \mathrm{krát}$, nyní až 500krát, cit. ${ }^{9}$ ). Př́irodní vanilka (extrakt $\mathrm{z}$ fermentovaných tobolek) ale kromě vanilinu obsahuje až několik stovek dalších látek, díky čemuž poskytuje spotřebiteli výrazně bohatší chut'ový a čichový zážitek. Na tento rozdíl narazily např́íklad firmy Pepsi-Cola Corp. a Coca-Cola Corp., které ji používají k ochucování svých hlavních produktů. Jejich roční spotřeba se pohybuje kolem 40 tun. Pokus o přechod na použití syntetického vanilinu v Coca-Cole v roce 1985 byl však spotřebiteli nepř́znivě přijat a firma se pak vrátila ke klasické receptuře 9 .

I když syntetický vanilin je důležitou chemikálií sloužící k výrobě farmaceutik, kosmetických, čisticích a herbicidních prostředků, je hlavně široce používán v potravinářském průmyslu. $Z$ porovnání světové produkce príirodní vanilky a syntetického vanilinu a hlavně $z$ dramatických cenových rozdílů vyplývá, že drtivá většina potravinářských a cukrářských výrobků získává vanilkovou vůni i chut' ze syntetického vanilinu'. V některých př́padech se původ odlišuje, známe např́klad běžné sáčky $\mathrm{s}$ aromatizovaným cukrem s nápisem ,vanilinový cukr“, ve kterých je ve $20 \mathrm{~g}$ cukru asi $6 \mathrm{mg}$ syntetického vanilinu, ale i dražší balení označená „vanilkový cukr“, ve kterých je cukr ochucen mletými vanilkovými lusky nebo jejich extraktem. Vzhledem k výše uvedenému by se tak měly běžné vánoční rohlíčky označovat jako „vanilinové““ a oblíbená zmrzlina by měla být také většinou „,vanilinováa“, což by ovšem tyto výrobky obchodně poškodilo.

I když postup britských vědců zatím nemá parametry průmyslové výroby, je velice perspektivní z ekologického pohledu. Závěr publikace obsahuje totiž důležité zjištění, že geneticky upravený kmen $E$. coli RARE_pVanX je schopen zpracovávat i surový hydrolyzát získaný z PET lahví pomocí termostabilní depolymerasy LCC WCCG (LCC - leaf-branch compost cutinase, WCCG - aminokyseliny cíleně mutované za účelem zvýšení aktivity a termostability enzymu - konkrétně jde o variantu F243W/D238C/S283C/Y127G) ${ }^{11}$. Postup tak umožňuje z obtížného odpadu získávat cenný produkt, což je zatím ojedinělý př́ípad.

Likvidace použitých PET lahví se stává celosvětově ožehavým problémem. Každou vteřinu se na světě prodá zhruba 20 tisíc plastových lahví. Každou minutu je to tedy více než milion. Vyplývá to $\mathrm{z}$ průzkumu britské společnosti Euromonitor International ${ }^{12}$, podle které jsou PET lahve globálně druhým nejčastěji používaným obalem, hned po plastových sáčcích.

Přestože je polyethylentereftalát recyklovatelný, představuje pro životní prostředí velkou hrozbu, která je podle studie $^{12}$ srovnatelná s globálním oteplováním. Úsilí lahve shromažd'ovat a znovu zpracovat už jednoduše nestačí tempu, jakým se vyrábějí nové. Vloni se na světě prodalo více než 480 miliard plastových lahví (i když jsou lehké, odpovídá to více než 13 milionům tun, cit. $\left.{ }^{13}\right)$. Předpokládá se další vzrůst o pětinu za každé 3 roky a do 20 let by se tak už roční výroba blížila 1 bilionu lahví. Podobná či ještě vyšší čísla udává i další zdroj ${ }^{14}$.

Evropská unie na tento stav reagovala vydáním Směrnice Evropského parlamentu a Rady (EU) 2019/904 ze dne 5. června 2019 o omezení dopadu některých plastových výrobků na životní prostředí ${ }^{15,16}$. Cíle směrnice o jednorázových plastových obalech vyžadují, aby v roce 2025 tříděný sběr za účelem recyklace dosahoval $77 \%$ odpadu z jednorázových plastových obalů do 3 litrů a povinnost prridávat do nápojových PET lahví alespoň $25 \%$ recyklátu. Do roku 2030 by pak indikátor sběru měl dosáhnout $90 \%$ a podíl přidaného recyklátu $\mathrm{v}$ PET lahvích $30 \%$. Jedním z opatření, jak toho docílit, může být dle obalové směrnice jejich zálohování. Zálohování PET lahví je zavedeno v Německu, Dánsku, Norsku, Islandu, Švédsku, Finsku, Estonsku, Litvě a Chorvatsku, prripravuje se zavedení zálohování na Slovensku a v Nizozemí ${ }^{17}$. Zpoplatnění, resp. zálohování lahví je účinným nástrojem pro omezení výskytu PET lahví v prrírodě a na skládkách. V Česku se prostřednictvím žlutých popelnic vytř́dí až čtyři pětiny PET lahví, čímž dnes země plní obalové cíle platné do roku 2025 (cit. ${ }^{15}$ ). Ministerstvo životního prostř̌edí ČR aktuálně neplánuje zavést zákonnou povinnost zálohování PET lahví a plechovek, protože to považuje za nekoncepční zásah do stávajícího systému třídění odpadů, více věří žlutým kontejnerům ${ }^{15}$. Souběh povinného zálohování a dobrovolného třídění by podle ministerstva přinesl řadu problémů, které by v důsledku mohly snížit celkovou míru třídění. Ekologové ale upozorňují, že Česko v budoucnu těžko splní požadavky Bruselu ${ }^{18}$.

Ministerstvo spoléhá na iniciativu jednotlivých výrobců nápojů, kteří si sami zajistí sběr a třídění použitých „vlastních“ lahví. Vysoké nároky na kvalitu vstupní suroviny jsou problémem všech postupů přímé materiálové recyklace, která se označuje jako B2B technologie (bottleto-bottle $)^{19}$. Zatím se v českém prostředí vyskytly dva př́pady použití této technologie. Pilotní projekt zálohovaných PET lahví Mattoni, které začal loni prodávat on-line supermarket Košík.cz, odstartoval v lednu 2020 (cit. $\left.{ }^{20}\right)$. Použité PET lahve vyrobené z 80\% recyklátu zákazníci vracejí nezmačkané kurýrovi proti tř́ḱkorunové záloze $\mathrm{v}$ podobě kreditů a takto vybrané lahve je možné znovu recyklovat. V roce 2021 uvedla společnost Coca-Cola na český trh stoprocentně recyklované PET lahve pro svou značku minerální vody Natura $\mathrm{v}$ rámci svého závazku ${ }^{21}$ plnit cíle směrnice EU. Uvedením nové recyklované PET lahve se Coca-Cola stává leaderem mezi výrobci v zavedení stoprocentně recyklované PET lahve pro jedno široké portfolio svých nápojů. 
PET lahve sebrané ze žlutých kontejnerů jsou různého druhu, a proto nejsou použitelné pro B2B technologie. Jen částečně se daři je vytřídit tak, aby z nich vznikl granulát, který lze použít jako podíl suroviny pro výrobu nových lahví. Většina se zpracovává materiálovou recyklací na užitečné výrobky, jako např́klad netkané textilie, technické tkaniny, koberce, provaznické výrobky nebo vláknité výplně používané hlavně jako čalounický materiál pro vnitřní výbavu automobilů ${ }^{18}$, nicméně po dožití takových výrobků již vzniká dále nevyužitelný odpad.

Všechny PET lahve (a rovněž veškeré výrobky $\mathrm{z}$ tohoto materiálu) lze teoreticky recyklovat chemicky, a to chemickou či enzymovou hydrolýzou polyesterového materiálu na jeho monomerní složky, tedy kyselinu tereftalovou a ethylenglykol. Po jejich vyčištění je pak možné polyethylentereftalát syntetizovat ,de novo“, což ovšem představuje složitější způsob recyklace. Tuto cestu snad nejúspěšněji řeší uskupení firem L'Oréal, Nestlé, Pepsi a Suntory, které se spojily s francouzskou společností Carbios $^{22,23}$. Ta po desetiletém výzkumu vyvinula enzym, který je schopný rozložit prakticky libovolnou PET lahev bez ohledu na barvu či komplexnost na monomery, přičemž revoluční je rychlost štěpení, která má být asi 10 000krát větší než u dosud využívaných postupů. Naprosto zásadní je $\mathrm{v}$ tomto př́padě skutečnost, že výstupem jsou monomery kyselina tereftalová a ethylenglykol v „panenské čistotě“. Díky kvalitě recyklovaných monomerů je z nich možno získat nové PET lahve s vlastnostmi plně srovnatelnými s těmi originálními, což by umožnilo provádět jejich recyklaci prakticky donekonečna. Společnost Carbios již spustila ověřovací provoz, závod s recyklační kapacitou 40000 tun by měl být otevřen před rokem 2025.

Na lehké, odolné a vzhledné PET lahve jsme si zvykli natolik, že se jich hned tak nevzdáme. Proto musíme podporovat recyklační strategie a intenzivně rozvíjet recyklační postupy. Vedle toho je třeba považovat použité PET lahve za výhodnou uhlíkatou surovinu pro jiné chemické výroby, v nichž by nahradily petrochemické materiálové vstupy, a tím pomohly nezvyšovat globální uhlíkovou zátěž. Př́kladem je postup britských vědců vedoucí $\mathrm{k}$ dobře využitelnému vanilinu. Je jasné, že výroba vanilinu z PET lahví svět nespasí a problematiku spojenou s nadměrnou produkcí PET lahví sama o sobě nevyřeší, ale mohl by to být první krůček, na který bude možné dále navazovat. Pokud se tento objev podaří rozvinout, možná bude skutečně vanilková příchut' zmrzliny vyráběna z PET lahví, kterým říkáme „,petky“, a proto takové zmrzlině nebudeme muset říkat vanilinová, ale třeba zajímavě znějícím názvem ,petková“ zmrzlina.

\section{LITERATURA}

1. https://program.rozhlas.cz/zaznamy\#/dvojka (1.7.2021), staženo 1. 7. 2021.

2. https://www.stoplusjednicka.cz/majstrstyk-recyklacevanilkova-prichut-vyrobena-z-plastovych-lahvi, staženo 8. 7. 2021.
3. https://www.flowee.cz/planeta/8856-z-plastovychlahvi-muze-byt-lukrativni-odpad-da-se-z-nich-vyrobit -vanilkova-prichut, staženo 8. 7. 2021.

4. Sadler J. C., Wallace S.: Green Chem. 23, 4665 (2021), doi: 10.1039/d1 gc00931a.

5. Kunjapur A. M., Tarasova Y., Prather K. L. J.: J. Am. Chem. Soc. 136, 11644 (2014).

6. Garner N., Siol A., Eilks I.: J. Sci. Educ. 17, 25 (2016).

7. https://en.wikipedia.org/wiki/Vanillin, staženo 8. 7. 2021.

8. https://skompasem.cz/nejvetsi-svetovi-producentivanilky-v-roce-2010/, staženo 21. 7. 2021.

9. https://cs.wikipedia.org/wiki/Vanilin, staženo 21. 7. 2021.

10. https://www.reflex.cz/clanek/zpravy/89438/co-vlastne -jime-a-pijeme-mene-nez-1-procento-vanilky-kterouznate-ze-zmrzliny-ci-coly-je-dnes-prirodni.html, staženo 21. 7. 2021.

11. Tournier V. a 19 spoluautorů: Nature 580, 216 (2020).

12. https://zpravy.aktualne.cz/zahranici/vice-nez-milionpet-lahvi-kupujeme-kazdou-minutu-konci-v-oce/ r $\sim$ 387ec3c5cc011e 79b340025900fea04/, staženo 21. 7. 2021.

13. https://www.imarcgroup.com/PET-bottlemanufacturing-plant, staženo 20. 8. 2021.

14. https://www.statista.com/statistics/723191/productionof-polyethylene-terephthalate-bottles-worldwide/, staženo 20. 8. 2021.

15. https://euractiv.cz/section/obehove-hospodarstvi/ news/mela-by-cr-zavest-povinne-zalohy-na-pet-lahveprirode-by-ulevily-mohly-by-vsak-vest-kezdrazovani, staženo 29. 9. 2021.

16. Smérnice Evropského parlamentu a Rady (EU) 2019/904 ze dne 5. června 2019 o omezení dopadu některých plastových výrobků na životní prostředí, https://eur-lex.europa.eu/legal-content/CS/TXT/PDF/, staženo 7. 9. 2021.

17. https://www.greenpeace.org/czech/tiskovazprava/10576/, staženo 7. 9. 2021.

18. https://www.novinky.cz/ekonomika/clanek/spor-ozalohovani-pet-lahvi-mzp-je-proti-ekologove-se-divi40303981, staženo 1. 9. 2021.

19. https://www.lidovky.cz/orientace/veda/doba-plastovaco-se-vyrabi-z-recyklovanych-pet-

lahvi.A190403_115920_ln_veda_ape/, staženo 7. 9. 2021.

20. https://www.mattoni1873.cz/pro-media/zalohovanamattoni-na-kosikcz-uzavira-kruh-a-recykluje-z-lahvedo-lahve, staženo 1. 9. 2021.

21. https://www.coca-cola.cz/tiskove-zpravy/recyklovanaPET-lahev, staženo 7. 9. 2021.

22. https://www.kupi.cz/magazin/clanek/14680-enzymypomohou-s-odpadem-loreal-nestle-a-pepsi-predstavily -rozlozitelne-pet-lahve, staženo 1. 8. 2021.

23. https://www.carbios.com/en/enzymatic-recycling, staženo 29. 9. 2021. 
P. Holý and E. Benešováa ${ }^{a}$ Department of Biochemistry and Microbiology, University of Chemistry and Technology, Prague): From PET Bottles to Sweet Delicacies

The treatment of waste PET bottles has become a pressing global issue over the last few decades, and many scientific teams are currently working on solutions to it. There are many different approaches of how to solve this problem. The present article outlines the possibility to process terephthalic acid, which is the hydrolysis product of polyethylene terephthalate, into vanillin, a compound widely used in the food industry. The work of British scientists who have succeeded in using genetic modification to produce a strain of $E$. coli RARE_pVanX capable of processing polyethylene terephthalate hydrolysates to the desired vanillin is presented in a broader context.

Keywords: vanillin, terephthalic acid, food industry, plastics, recycling

- Holý P., Benešová E.: Chem. Listy 116, 61-64 (2022).

- https://doi.org/10.54779/chl20220061 